\title{
A REESTRUTURAÇÃO DO COLÉGIO UNIVERSITÁRIO DA UFMA NO PROCESSO DE URBANIZAÇÃO DE SÃO LUÍS (1960-1980)
}

\author{
SAMUEL LUIS VELÁZQUEZ CASTELLANOS ${ }^{1}$ \\ ORCID: https://orcid.org/0000-0003-0849-348X \\ WILSON RAIMUNDO DE OLIVEIRA ${ }^{2}$ \\ ORCID: https://orcid.org/0000-0001-6165-2924
}

\begin{abstract}
RESUMO: Neste artigo debate-se o processo de implantação e instalação do Colégio Universitário da Universidade Federal do Maranhão no contexto de modernização do ensino no estado (1960/1980) e de sua transferência e reestruturação para o bairro periférico da Vila Palmeira em São Luís como Colégio de Aplicação. Analisa-se a conjuntura político-educacional que viabilizou a remoção desta unidade integrada do campus universitário como modalidade escolar de escolarização restrita a uma pequena e seletiva clientela, para uma comunidade pobre na periferia da capital. Apontam-se os confrontos entre estratégias impostas pela política educacional/gestão funcionalista do estado, e táticas de apropriação dos professores, funcionários, alunos, lideranças e organizações comunitárias pertencentes a uma cultura local, que em função de interesses interligados, defenderam a instituição como instância de pertença, permanência e sobrevivência. Utilizam-se jornais, legislação e documentação do arquivo escolar como fontes norteadas pelo referencial teórico-metodológico da história cultural. Conclui-se que a defesa constante da comunidade local, professores e funcionários pelo papel/lugar do Colégio de Aplicação como imagem simbólica e concreta de superação neste bairro suburbano e sua efetivação como escolalaboratório, campo de estágio e espaço de educação permanente e de adultos, se constitui numa moeda de troca destes indivíduos para ter acesso ao mercado de bens simbólicos e um caminho para capitalizar possibilidades de ascensão social via sucesso escolar.
\end{abstract}

Palavras-chave: Colégio Universitário, História da Educação, Maranhão, ensino de segundo grau, Lei $\mathrm{n}^{\circ} 5.692$.

\footnotetext{
${ }^{1}$ Universidade Federal do Maranhão (UFMA). São Luis, MA, Brasil. <Samuel.vcastellanos@gmail.com> Doutor em Educação Escolar pela Universidade Estadual Paulista “Júlio de Mesquita Filho" (2012), com pós-doutorados em Educaçao pelo Centre d'histoire culturelle des sociétés contemporaines da Université de Versailles Saint-Quentin-en-Yvelines (2015) e pela Universidade Federal de São Paulo - UNIFESP (2019). Professor Associado I do Departamento de Educação I da Universidade Federal do Maranhão (UFMA).<Samuel.vcastellanos@gmail.com>

${ }^{2}$ Universidade Federal do Maranhão (UFMA).São Luis, MA, Brasil.<wilsondasapucaia@gmail.com>

Mestre em Educação pela Universidade Federal do Maranhão (UFMA), Brasil. Técnico em assuntos educacionais desta mesma instituição.
} 


\section{THE RESTRUCTURING OF THE UFMA UNIVERSITY COLLEGE IN SÃO LUÍS URBANIZATION PROCESS}

(1960-1980)

ABSTRACT: This article discusses the process of implementation and installation of the University College of the Federal University of Maranhão in the context of the modernization of education in the state (1960-1980) and its transfer and restructuring to the peripheral neighborhood of Vila Palmeira in São Luís as an Application College. The political-educational conjuncture that made possible the removal of this integrated unit from the university campus as a schooling modality restricted to a small and selective clientele, to a poor community in the outskirts of the capital is analyzed. The confrontations between strategies imposed by the educational policy/functionalist management of the state, and tactics of appropriation of teachers, employees, students, leaders and community organizations belonging to a local culture, which in function of interconnected interests, defended the institution as an instance of belonging, permanence and survival, are pointed out. Newspapers, legislation, and documentation from the school archives are used as sources guided by the theoretical and methodological framework of cultural history. We conclude that the constant defense of the local community, teachers and employees for the role/place of the Colégio de Aplicação as a symbolic and concrete image of overcoming in this suburban neighborhood and its effectiveness as a school-laboratory, internship field and space for permanent and adult education, constitutes a currency of exchange for these individuals to have access to the market of symbolic goods and a way to capitalize possibilities of social ascension via school success.

Keywords: University College, History of Education, Maranhão, high school education, Law No. 5.692.

\section{LA REESTRUTURACIÓN DEL COLEGIO UNIVERSITARIO DE LA UFMA EN EL PROCESO DE URBANIZACIÓN DE SÃO LUÍS (1960-1980)}

RESÚMEN: En este artículo se debate el proceso de implantación e instalación del Colegio Universitario de la Universidad Federal de Maranhão en el contexto de modernización de la enseñanza en el estado (1960/1980) y de su transferencia e reestruturación para el barrio periférico de la Vila Palmeira en São Luís como Colegio de Aplicación. Se analisa la conyuntura político-educacional que viabilizó la remoción de esta unidad integrada del campus universitario como modalidad escolar de escolarización restricta a una pequeña y selectiva clientela, para una comunidad pobre en la periferia de la capital. Se apontan los confrontos entre estrategias impuestas por la política educacional/gestión funcionalista del estado e tácticas de apropiación de los profesores, funcionarios, alumnos, lideranzas y organizaciones comunitarias pertenecientes a una cultura local, que en función de intereses interligados, defendieron la institución como instancia de pertenecimiento, permanencia y sobrevivencia. Se utilizan periódicos, legislação y documentación del archivo escolar como fuentes examinadas a la luz del referencial teórico-metodológico de la historia cultural. Se concluye que la defesa constante de la comunidade local, profesores y funcionarios por el papel/lugar del Colegio de Aplicación como imagen simbólica y concreta de superación en este barrio arrabalero y su efetivación como escuela-laboratorio, campo de práctica y espacio de educación permanente y de adultos, se constituye en una moneda de cambio de estos individuos para tener acceso al mercado de bienes simbólicos y un camino para capitalizar posibilidades de ascensión social vía éxito escolar.

Palabras clave: Colegio Universitario, Historia de la Educación, Maranhão, enseñanza secundária, Ley $n^{\circ} 5.692$. 


\section{INTRODUÇÃO}

A modernização do ensino no estado do Maranhão ganhou impulso principalmente a partir dos anos 1960 (KREUTZ, 1982; PINTO, 1982; NASCIMENTO, 2013). Década em que ocorre uma ruptura intra-oligárquica (FAUSTO, 1997), responsável pela eleição do governador José Sarney como líder político, que encabeçou a tentativa de modernizar política e economicamente a sociedade maranhense, ao superar o antigo pacto coronelista e inaugurar o período caracterizado pelo alinhamento com projetos desenvolvimentistas do regime civil-militar; planos que incluíam o Maranhão na rota do progresso agroindustrial. Assim, deflagrou-se o chamado "milagre maranhense", expressão inventada como símbolo do investimento em infraestrutura; estratégia política materializada na construção de estradas, pontes, obras de eletrificação e outras ações que promoveram transformações socioespaciais, gerando entre outros efeitos, a grande explosão demográfica na capital São Luís, que demandou a reestruturação dos serviços públicos, notadamente educacionais.

Esse governo (1966-1970), sustentado na retórica desenvolvimentista do "Maranhão Novo", colocou em prática estratégias político-sociais típicas do regime civil-militar: abriu e pavimentou estradas; construiu a usina hidroelétrica de Boa Esperança; viabilizou a construção do Porto do Itaqui; desenvolveu programas habitacionais para a classe média, principalmente, na capital, em meio a outras ações. "Energia e transporte constituiriam aspectos [infraestruturais] para o passo seguinte que seria a industrialização e a montagem de grandes projetos [agropecuários] no Maranhão" (PINTO, 1982, p. 84). Estabelecia-se, deste modo, a ideia do "milagre maranhense" dentro do "milagre brasileiro"; expressão utilizada pelos entusiastas da ditadura naquele contexto.

Mas a ordem social almejada por esta gestão funcionalista (CERTEAU, 2012) nunca existiu, pois se considerarmos as novas perspectivas econômicas, que demandavam altos investimentos financeiros para o setor agrário, ao valorizarem-se imensidões de terras ocupadas por posseiros que acabaram migrando para a capital em busca de uma vida melhor, resta-nos o cenário caótico formado pelo êxodo rural e pela explosão urbana de São Luís: cidade de grandes contrastes sociais, onde não havia nem emprego em quantidade suficiente para absorver toda a população que chegava dos vários rincões maranhenses nem oferta de serviços públicos capaz de atender tão numerosa concentração humana. Em outras palavras, tal desordem urbana impactou o quadro social e intensificou o abismo entre luxo e pobreza.

Os movimentos reivindicatórios que surgiram, por outro lado, acabaram exigindo do estado alguma resposta no sentido de prover, ainda que minimamente, o acesso da população à saúde pública e à educação, entre outros setores. Configuração social que engendrou estratégias governamentais de ampliação da rede estadual de ensino. Ações que tiveram início em 1966, quando houve uma forte pressão da sociedade ludovicense por vagas nas escolas primárias. Na ocasião, a Secretaria estadual de educação afirmara, via imprensa, que "[...] na forma de recomendação do governo, o problema est[ava] praticamente resolvido, com a instalação e funcionamento de novos turnos intermediários na maioria dos grupos escolares da capital e do interior.” (O IMPARCIAL, 1966, p. 4).

Na gestão do Dr. José Maria Cabral Marques, secretário estadual de educação (1967-1970), se expandiu o número de matriculados em todo o estado, ao se adotarem as seguintes medidas: o Projeto João de Barro (1967), destinado a criar escolas rurais primárias no interior do estado; o Projeto Bandeirante (1968), voltado para a criação de ginásios (primeiro ciclo do Ensino Médio), principalmente nas cidades interioranas, mas também em São Luís e o Projeto TV Educativa (1969), cujo escopo era a expansão do ensino médio na capital e nas maiores cidades, além da formação profissional de jovens e adultos (KREUTZ, 1982; PINTO, 1982; NASCIMENTO, 2013). Paralelamente, ocorria a inauguração da Fundação Universidade do Maranhão (federal) e o "[...] funcionamento das Faculdades de Engenharia, Administração e Pedagogia, que oferece[ra]m oportunidades de qualificação de técnicos de nível superior reclamada pelo próprio processo de desenvolvimento" (O IMPARCIAL, 1968e, p. 8) na ordem estadual.

Mesmo assim, restavam aos anos 1970 enormes desafios: 66\% das crianças do interior e 23\% da capital estavam fora da escola primária; o ensino médio continuava em sua maior parte nas mãos de instituições privadas e o ensino superior apenas engatinhava. Contexto em que a pressão social, econômica e política se avolumava, comprometendo o discurso do "Maranhão Novo", tornando-o pouco palatável. Fortes tensões se avizinhavam e era urgente a elaboração de novas estratégias político- 
educacionais; “[...] ações, que graças ao postulado de um lugar de poder [...] elaboram lugares teóricos [...] capazes de articular um conjunto de lugares físicos onde as forças se distribuem" (CERTEAU, 2012, p. 102).

Particularmente grave era a situação da capital, agitada pela explosão demográfica que fazia surgir bairros sem nenhuma estrutura urbana. Nesse sentido,

Fato novo na história educacional do Maranhão e que bem indica o acerto que o dr. José Maria Cabral Marques [vinha] imprimindo a essa Secretaria é de estar a Divisão de Ensino Primário oferecendo mais de 1600 vagas de ensino elementar nas unidades escolares da Capital depois de ter ampliado em 4000 as matrículas do Primário para o corrente ano letivo. Segundo aviso que [tinha] sido publicado nos últimos dias pela imprensa, exist[ia]m vagas para matrícula em numerosos grupos escolares de São Luís e os interessados poder[iam] até terça-feira próxima efetuar matrícula de seus filhos nas [...] unidades que ainda dispõem de vagas (JORNAL DO DIA, 1968b, p. 5)

Paralelamente a estas medidas, a Fundação Universidade do Maranhão (FUM), em 1968, decidiu "[...] criar o Colégio Universitário, destinado a alunos que cursa[va]m o $3^{\circ}$ ano do curso colegial e, portanto, se prepara[va]m a ingressar numa escola superior (JORNAL DO DIA, 1968c, p.1); oferta ampliada pelo regimento interno da instituição elaborado em 1972, que modificava sua natureza num Colégio de Aplicação, transformado em "[...] Campo de estágio, experimentação e aplicação da Faculdade de Educação" (SANTOS, 2012, p. 61). Tal mudança ocorreu no contexto de implementação da Lei 5.692, de 11 de agosto de 1971, que determinara, entre outras alterações, a transformação do colegial (segundo ciclo do Ensino Médio) em um $2^{\circ}$ grau de três anos com características profissionalizantes. Com isso, a partir de 1974, o Colégio Universitário passou a oferecer vagas desde o $1^{\circ}$ ano do $2^{\circ}$ grau em três habilitações profissionais: Administração, Estatística e Secretariado. Contudo, como campo de estágio e experimentação metodológica, seu funcionamento ficou comprometido por razões diversas: o quadro docente era reduzido, dificultando a prática do estágio supervisionado; a seletividade discente era elevadíssima, distanciando os estagiários da realidade educacional vivenciada pela maioria das escolas públicas; a estrutura física era imprópria, visto que a referida instituição ocupou salas do Palácio Cristo Rei e de outros prédios da universidade tanto no centro histórico da capital maranhense como também na cidade universitária situada na Vila Bacanga; enfim, a ausência do $1^{\circ}$ grau (etapa concebida na reforma educacional de 1971 pela unificação entre os antigos primário e ginásio) limitou consideravelmente a atuação prevista por aquele regimento.

Outras tentativas de modernização educacional surgidas nesse período ganharam vida no Programa de Expansão e Melhoria do Ensino Médio (PREMEM) ${ }^{3}$, centrado "[n]o aprimoramento do ensino médio, no nível ginasial [que] deve[ria] ser estimulado com o aumento do número de escolas polivalentes" (BRASIL, 1968, p. 454) e no Programa de Expansão e Melhoria do Ensino (PREMEN) ${ }^{4}$, que objetivara "[...] aperfeiçoar o sistema de ensino de primeiro e segundo graus no Brasil" (BRASIL, 1972, p. 164); experiências que foram responsáveis pela construção de instituições escolares de grandes dimensões na capital e nas maiores cidades do interior do estado. Estruturas arquitetônicas que deveriam ter viabilizado a reforma, se não fosse o descaso governamental que em parte as entregara ao abandono, abrindo-se caminho para o confronto entre estratégias político-educacionais geradas no âmbito tecnocrático e táticas de apropriação populares no que tange ao uso desses espaços de ensinoaprendizagem, destacando-se a reestruturação do Colégio Universitário pelo acordo que envolveu a Secretaria Estadual de Educação (SEDUC) e a Universidade Federal do Maranhão (UFMA), resultando por um lado, na transferência deste Colégio para um complexo escolar construído na Vila Palmeira via PREMEN, e por outro, no ingresso de crianças, adolescentes, jovens e adultos da periferia de São Luís nesta unidade acadêmica especial da UFMA.

Destarte, neste trabalho analisamos até que ponto a trajetória do Colégio Universitário da Universidade Federal do Maranhão desde sua concepção, implantação e instalação, até sua transferência e reestruturação como Colégio de Aplicação para o bairro pobre de Vila Palmeira com uma dinâmica específica foi norteada pelos confrontos constantes e de mão dupla entre as estratégias de imposição da

${ }^{3}$ Decreto n 63.914, de 26 de dezembro de 1968.

${ }^{4}$ Decreto ${ }^{\circ} 70.067$, de 26 de janeiro de 1972. 
política educacional do governo e do estado, com as táticas de apropriação dos sujeitos atuantes no cenário educacional como professores e funcionários, e os indivíduos do lugar pertencentes a uma cultura local? Para tanto, apoiados nos aportes teórico-metodológicos da história cultural, recorremos a indícios já elencados nos jornais da época que foram cruzados com informações garimpadas na legislação vigente e no arquivo escolar da instituição, considerando-se aqui a imprensa como fonte privilegiada, por entendermos a importância dos jornais locais reunidos em um "[a]cervo que - ao estar armazenado na Biblioteca Pública 'Benedito Leite', reconhecida esta como grande depositária da memória (desde o Império até o tempo presente), da cultura, das artes e da política maranhense - não só [nos] possibilitou o resgate do cotidiano da capital são-luisiense, como também o passado-presente de outras localidades interioranas" (CASTELLANOS, 2012, p. 43), permitindo-nos compreender o panorama político, econômico e educacional maranhense no período proposto.

\section{A VILA PALMEIRA}

Em São Luís, no final da década de 1960, como parte da estratégia midiática do "Maranhão Novo", o governo difundiu pela imprensa representações do estado sob o signo do progresso. Em janeiro de 1968, comemorando-se os dois anos daquela gestão, foram " [...] inauguradas pelo chefe do executivo as 505 casas construídas no [bairro do] Anil, pela Companhia de Habitação Popular do Maranhão, [por meio do] financiamento do BNH [Banco Nacional de Habitação].” (O IMPARCIAL, 1968a, p.8), e entregues pelo Departamento de Estradas e Rodagens (DER) os 18 quilômetros asfaltados do Campo de Perizes na BR 135; “[...] rodovia redentora [onde] roda[va]m veículos de todo tipo, desde pesados caminhões de carga de toda parte do país até ônibus de luxo e os grandes aerowillis ou galaxios" (O IMPARCIAL, 1968c, p. 4). Nessa lógica, a tentativa de decifrar de outro modo a sociedade, nos autoriza a penetrar na meada das relações/tensões que a constituem a partir de "[...] uma rede de práticas específicas, e [a considerar] não haver prática ou estrutura que não seja produzida pelas representações, contraditórias ou em confronto, pelas quais os indivíduos e os grupos dão sentido ao mundo que é o deles" (CHARTIER, 2005, p. 177). Destarte, a força da representação atingiu,

[...] o ponto alto das comemorações [...] a inauguração da ponte sobre o rio Anil, no Bairro do Caratatiua na nova estrada que, ligando aquele bairro ao balneário do Olho Dágua encurta em muitos quilômetros a distância entre a capital e aquela praia, devendo receber a mesma o nome "Castelo Branco", em homenagem ao falecido presidente Humberto de Alencar Castelo Branco [...] inauguração do Grupo Escolar do Barreto [e] da pavimentação da avenida João Pessoa, no Bairro do João Paulo (JORNAL DO DIA, 1968a, p. 1).

A obra-símbolo do "milagre maranhense" era o Porto do Itaqui, cujos trabalhos em andamento ensejaram a construção da Barragem do Bacanga e a projeção de uma cidade industrial na margem esquerda daquele rio, o que acabou provocando um "[...] alargamento do número de habitantes [que] ocorreu, em parte, pelo crescente êxodo do campo para a cidade, em virtude da grilagem, da violência e da desintegração da comunidade rural que conduziu o contingente de trabalhadores às periferias dos núcleos urbanos (SOUZA, 2018, p. 44); aumento da malha urbana da capital na direção oeste que deu origem à urbanização do eixo Itaqui-Bacanga. Estratégias políticas que tinham o sentido de estabelecer as bases para o desenvolvimento do capitalismo industrial.

Mais de 2 bilhões de cruzeiros investiu o governo Sarney em 1967 em obras de urbanismo na capital maranhense, das quais a mais significativa [é] a de asfaltamento de 30 quilômetros de ruas e avenidas. Foram ainda iniciadas as obras de urbanização do Distrito Industrial do Itaqui e barragem do Bacanga. A secular São Luís, preservada sua arquitetura, moderniza-se como centro dinâmico de um processo de desenvolvimento (O IMPARCIAL, 1968d, p. 12).

Apesar desses investimentos em infraestrutura, não houve um planejamento urbanístico que levasse em conta o crescimento acelerado da população. Em pouco tempo, formou-se um cenário urbano caótico, que "[...] culmina em um processo de grande crescimento da população [...] e um gradativo inchaço da cidade que em vias de infraestrutura não atende toda a demanda que se instala nas áreas centrais e principalmente nas áreas periféricas de São Luís (MOREIRA, 2013, p. 44). Terras às margens 
dos rios Anil e Bacanga e dos mangues que ao serem invadidas por populações de baixa renda e pela grilagem urbana, ampliam o espaço habitado da cidade tanto na direção leste, como na oeste.

\begin{abstract}
A cidade de São Luís, cujo perímetro urbano é uma faixa compreendida entre os braços de mar, [nas] desembocaduras dos rios Anil e Bacanga, tem expansão multiforme segundo o eixo [1]esteoeste. Cidade de paisagem urbanística com predominância de sobrados e sobradões coloniais, que fazem contraste com algumas novas residências por um lado e por outro com a miséria das palafitas dos alagados e casebres das favelas. Dentro do panorama mundial hodierno, um dos aspectos mais aflitivos em São Luís é o da carência de habitação em termos de satisfação de padrões mínimos, que dependem do nível econômico a ser atendido, de fatores tecnológicos e locais como clima, aspectos sócio-culturais e outros. Pela análise da composição de renda e seu nível, São Luís se apresenta como das mais pobres no Brasil. Fatores como alto índice de desemprego, expansão industrial de recentíssimo “take off”, baixa produção de energia elétrica, cujo custo ainda não atinge níveis econômicos e a riqueza do setor primário e terciário na formação da renda de todo o estado, concorrem para a pouca circulação de capital. Uma família tendo em média seis pessoas e com uma renda entre um a dois salários mínimos, pouco consegue prover-se em suas necessidades básicas. Com um crescimento demográfico explosivo, baixo índice de construções para fins habitacionais (índice este cuja curva está em ascensão, porém muito aquém da necessidade) e com uma renda per capita crítica, o problema habitacional de São Luís tende a agravar-se cada vez mais. A procura de emprego por aqueles que compõem a faixa do êxodo rural torna-se cada vez mais intensa, concorrendo para verdadeira corrida de aluguéis de residências. Sobre este tema disse o arquiteto Sérgio Bernardes: "cada estrada que vai em busca de riqueza, promove o êxodo rural. As populações que largam o interior em busca de melhores dias, pela oportunidade de empregos, esvaziam áreas que são de complementação mineral dos países desenvolvidos ou esvaziam uma área de complementação agrícola de uma população faminta". A ausência de ofertas de moradias em São Luís, força, por seu turno, a formação de conglomerados de cerca de oito famílias em média de quarenta e cinco pessoas em verdadeiros pardieiros ou na multiplicação de favelas (O IMPARCIAL, 1968b, p. 4).
\end{abstract}

Contexto em que a cidade, até então circunscrita aos dois "braços de mar" onde desembocam os rios Anil e Bacanga, com o seu centro beirando a Baía de São Marcos, começou a expandir-se e se saiu do seu núcleo urbano inicial (ver figura 1). A ausência de ofertas de moradias e a formação de conglomerados que expunham a miséria das palafitas dos alagados e casebres das favelas, o alto índice de desemprego versus a corrida de aluguéis de residências pelos interioranos, a expansão industrial recentíssima, a baixa produção de energia elétrica e a pouca circulação de capital na cidade, fizeram que se mobilizassem estratégias governamentais concretas para evitar-se o sufoco urbano; novos bairros foram criados em espaços inabitáveis que disciplinariam o solo e diminuiriam as desigualdades como meta do projeto de despalafitação e contenção (FERREIRA, 2014). Nessa dinâmica, a Companhia de Habitação Popular do Maranhão (COHAB) construiu os conjuntos residenciais nas proximidades da nascente do Rio Anil mediante empréstimo concedido pelo $\mathrm{BNH}$; casas que foram entregues em várias etapas, dando origem aos conjuntos Anil I, Anil II e Anil III. Sistema de crédito financeiro pelo qual a Caixa Econômica também construiu o residencial Yolanda da Costa e Silva no bairro do Caratatiua.

Para interligar esses diferentes pontos foram erguidas pontes e artérias urbanas que embelezariam a cidade se não fossem as desordens provocadas pelo êxodo rural, conflitos que se agravaram muito a partir da promulgação da Lei de Terras, de 1969, que expulsou as populações do campo, as quais se alojaram nos "vazios" entre os bairros da capital; famílias abrigadas no bairro da Camboa, na Via Kennedy e na Vila Macaúba, que se em 1968 eram caracterizadas como "[...] gente sem chão próprio, [...] mundo dos que suam para sobreviver e que vão sendo empurrados pelo progresso, forçados a se batraquearem, mas que sonham poderem algum dia ter casa de alvenaria coberta de telha" (O IMPARCIAL, 1968f, p. 7), em anos posteriores, continuam figurando no cenário da urbe ludovicense em número cada vez maior, e participam das lutas populares pela efetivação da cidadania, embora em condições desfavoráveis. Equilíbrio de tensões que marca as lutas de representações, cuja questão é o ordenamento, portanto a hierarquização da própria estrutura social; “[...] estratégias simbólicas que determinam posições e relações e que constroem, para cada classe, grupo ou meio, um ser-percebido constitutivo de sua identidade" (CHARTIER, 2005, p. 184). Palafiteiros que tinham plena consciência da sua condição de clandestinidade, pela qual 
Algum dia a gente tem que sair daqui. Quando já não houver mais mangue, as marés forem afastadas e os "brancos" puderem construir seus bangalôs. Virão tratores, as máquinas pesadas e a gente apanha a trouxa e finca estaca em outro pedaço de mangue sem dono. É sempre assim. Nós é que entulhamos a cidade (O IMPARCIAL, 1968f, p. 7).

Multidão inumerável de famílias que saíram do campo em busca de uma vida melhor e lutavam pelo "direito à cidade" (LEFEBVRE, 2001). Indivíduos que, atraídos pelo centro do progresso, ao mesmo tempo em que eram excluídos por ele, se negaram a abandoná-lo, criando espaços imprevistos de atuação. Nessa lógica, se as estratégias apontavam "[...] para a resistência que o estabelecimento de um lugar oferece[u] ao gasto do tempo; as táticas aponta[ra]m para uma hábil utilização do tempo, das ocasiões que apresenta e também dos jogos que introduz nas fundações de um poder" (CERTEAU, 2012. p. 102), na medida em que, o palafiteiro ou o suposto pobre de um interior qualquer ou de um nãolugar na cidade, acreditava que:

Se fôssemos contar cabeça por cabeça a gente que vive sobre o mangue, disputando espaço com chama-maré talvez somássemos [...] beirando as sete mil almas. Mas nem as estatísticas oficiais nem o IBOP podem informar com exatidão: porque o palafiteiro mina. Parece que tem um pacto com as marés, nesse ir e vir entre as vazantes e as preamares (O IMPARCIAL, 1968f, p. 7).

Este não lugar, que remete aos modos de fazer o espaço urbano por parte de sujeitos desprovidos de um lugar (CERTEAU, 2012), impeliu seus moradores a buscarem melhores condições de sobrevivências, ocupando terrenos mais firmes em áreas ainda não alcançadas pela especulação imobiliária e tampouco beneficiadas por projetos governamentais. Urbanizaçao descontrolada que acentuou o contraste social verificado nas formas de habitação da cidade, pois "[e]nquanto os bairros da orla marítima e os da área nobre do Rio Anil são dotados de [infraestrutura], os outros bairros, em grande parte, não possuem o mínimo em termos de saneamento" (SILVA, 1987, p. 31-32); táticas de apropriação e resistência que fizeram surgir bairros periféricos, como a Vila Palmeira que, em pouco tempo se tornaria uma das maiores aglomerações humanas da capital. Representações que invocam "[...]contra as determinações imediatas das estruturas as capacidades inventivas dos agentes, e contra a submissão mecânica à regra as estratégias próprias da prática” (CHARTIER, 2005, p. 176).

Figura 1. Urbanização da ilha de São Luís do Maranhão.

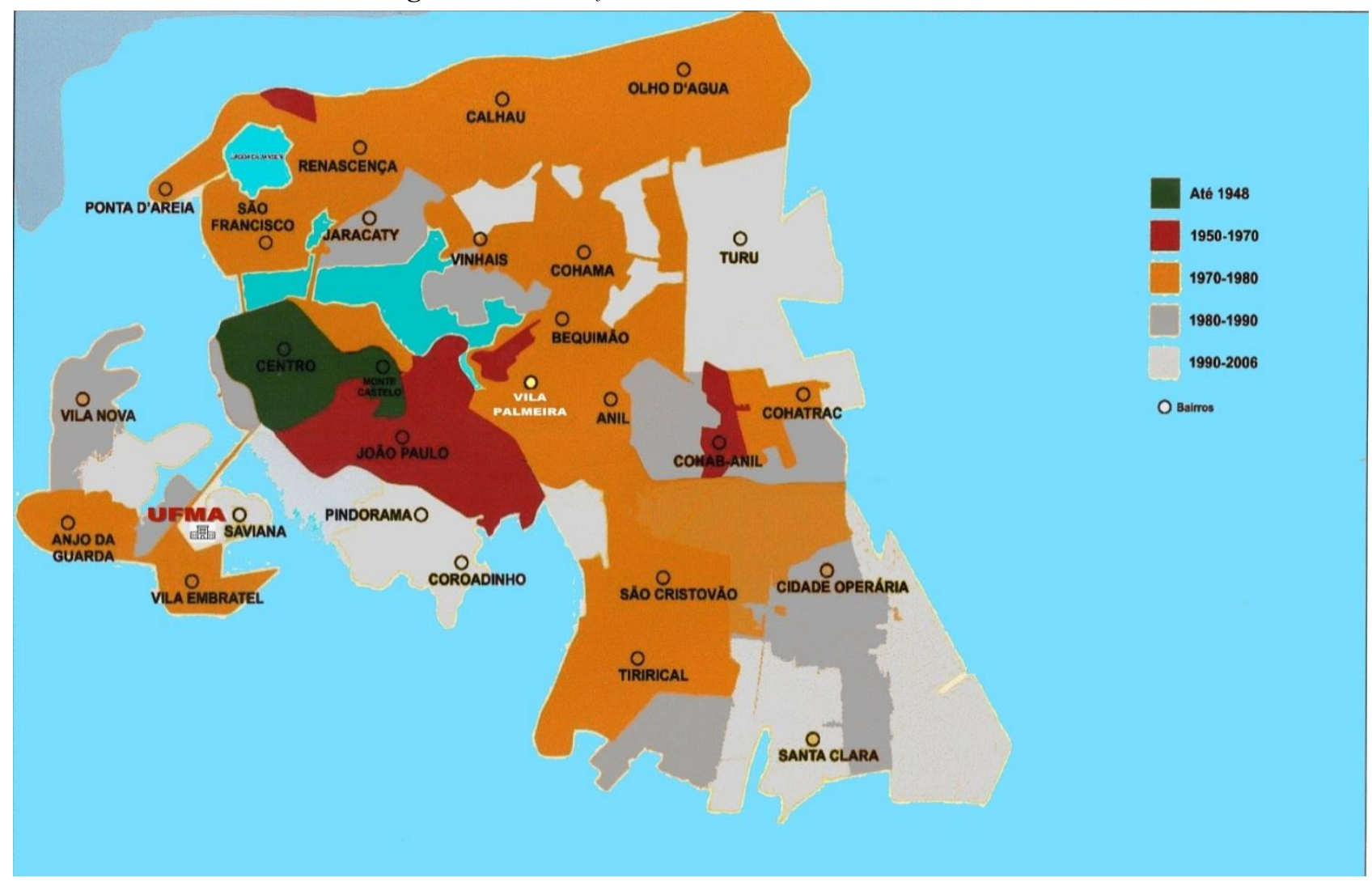


Fonte: Adaptação dos autores a partir de Souza (2018, p. 46).

Por este mapa, percebemos os movimentos de expansão da cidade: a área restrita às proximidades do centro histórico até 1948 (cor verde); a formação do Bairro João Paulo e os conjuntos habitacionais da COHAB até 1970 (cor vermelha); o surgimento dos empreendimentos residenciais COHAMA, Bequimão e COHATRAC; a conformação do Renascença, São Francisco e Ponta D’Areia (bairros de classe média e alta), paralelamente ao crescimento das comunidades periféricas do Anjo da Guarda, Vila Embratel e Vila Palmeira até 1980 (cor alaranjada), entre outras ocupações posteriores. Destacamos aqui a distância estabelecida entre a Universidade Federal do Maranhão e a Vila Palmeira via localização; bairro periférico próximo ao mar e às nascentes do Rio Anil para onde o Colégio Univesitário da UFMA se transferia e reestruturara como Colégio de Aplicação, localidade onde casebres e palafitas deram origem a uma "cidade sobre o mangue"construída pelas táticas de apropriação de quem não planeja simplesmente porque não possui um lugar e, assim, representam a expectativa de uma vitória do tempo sobre o lugar, já que jogam de acordo com a ocasião porque sendo originárias de um não lugar, elas dão golpes, agem por astúcia e, atentas a cada lance, não propõem o jogo, mas ficam na defensiva e apostam no contra-ataque (CERTEAU, 2012).

Pela Lei Municipal n 1904, de 21 de setembro de 1970, “[...] fica denominada Vila Palmeira a localidade situada à margem esquerda da Avenida dos Franceses, entre a Vila Ivar Saldanha e o trecho do Outeiro da Cruz" (LIMA, 2002, p. 228). Originada no panorama de explosão demográfica que atingiu a capital maranhense desde o final dos anos de 1960, esta Vila resultou inicialmente, da ocupação de terrenos às margens do Rio Anil por famílias pobres vindas de áreas rurais do interior do estado em busca de empregos prometidos pela propaganda desenvolvimentista do governo, que anunciava uma era de prosperidade baseada no crescimento econômico (SILVA, 1987), como se este por si só pudesse resolver os conflitos sociais que, na verdade, derivam de várias formas de desigualdade. Contradições que resultaram no engajamento popular e lutas pela efetivação da cidadania, incluindo-se não só os direitos à moradia, ao saneamento básico, à assistência social e aos serviços médicos por parte do estado, mas também o direito à educação pública cuja oferta não se materializaria no local até os finais de 1970. Histórico de lutas que repercutira na reestruturação do Colégio Universitário a partir de uma comunidade urbana pobre e culturalmente estruturada em traços rurais/urbanos. Cultura popular local que influenciou a cultura escolar e a dinâmica específica do Colégio de Aplicação da UFMA que se fez única.

A partir da década de 1970, diante da especulação imobiliária que supervalorizava os terrenos, paralelamente à ocupação das áreas mais valorizadas da cidade por grupos sociais de maior poder aquisitivo, formando os bairros do São Francisco, Renascença, Calhau, Olho D'água e Ponta da Areia, outras cooperativas habitacionais desenvolveram programas semelhantes aos da $\mathrm{COHAB}$, que resultaram no surgimento de novos conjuntos: Cohatrac, Turu, Vinhaes, Cohama, Cohafuma, Bequimão, dentre outros. No entanto, a política habitacional não abarcou as famílias atingidas pelo "[...] drama por que passa[va] o bairro de coroados, um amontoado de mais de oitocentos barracos existente atrás do bairro da cerâmica" (O IMPARCIAL, 1972a, p. 6).

Comunidades como a de Coroados, Vila Palmeira e dezenas de outras em vários pontos da cidade eram representadas pelo termo "invasão" porque seus moradores não tinham títulos das propriedades ocupadas. O disciplinamento do solo urbano por parte da Prefeitura encontrou variadas formas de resistência, desde a reconstrução das casas derrubadas pela polícia, descambando muitas vezes para a violência, até a criação da "União de Moradores" em cada bairro, como forma de organização comunitária que acabou reconhecida pela Prefeitura; ou seja, às estratégias de imposição próprias de uma gestão funcionalista (do governo municipal), responderam aqueles personagens desprovidos de um lugar, com suas táticas de apropriação, jogando de acordo com as circunstâncias e, ao fazê-lo, foram sabotando a ordem urbana sem necessariamente alterá-la; sobrevivendo subterraneamente por uma atividade inumerável (a construção de casebres sem registro de imóvel) que teimosamente desdobrou-se em mil maneiras de fazer, inventando outras práticas (esporte, lazer, comércio etc) cada vez mais heterogêneas (CERTEAU, 2012) que também podem ser lidas como práticas culturais, se considerarmos que estas dizem respeito

[...] não apenas [à] feitura de um livro, uma técnica artística ou uma modalidade de ensino, mas também [a]os modos como, em uma dada sociedade, os homens falam e se calam, comem e 
bebem, sentam-se e andam, conversam ou discutem, solidarizam-se ou hostilizam-se, morrem ou adoecem, tratam seus loucos ou recebem os estrangeiros.”(BARROS, 2003, p. 157).

Configuração social que, ao possibilitar o surgimento de lideranças e organizações comunitárias (União de moradores, escolas improvisadas, congregações religiosas etc), disseminou entre os seus agentes o espírito reivindicatório e os estimulou a lutar pela urbanização do local, assim como pelo direito a um Colégio de Aplicação mais tarde que garantiria em tese o ensino secundário a toda a população do bairro com faixa etária determinada em lei para este nível de ensino. Redes de dependências recíprocas "[...] que fazem com que cada ação individual dependa de toda uma série de outras, porém modificando, por sua vez, a própria imagem do jogo social [...] que pode representar esse processo permanente de relações em cadeia [...]". (ELIAS, 2001, p. 13). Práticas educativas que "[...] atua[ra]m e influencia[ra]m a vida dos sujeitos de modo amplo, difuso e imprevisível" (FRANCO, 2016, p. 536), inculcando neles o desejo de consumir os bens culturais proporcionados pelo exercício da cidadania.

Em 1972, a Sociedade de Melhoramentos e Urbanismo da Capital (SURCAP), em parceria com o Departamento Nacional de Obras e Saneamento (DNOS), aterrou uma área alagada na margem direita da Avenida Kennedy, em local próximo ao Bairro de Fátima, onde viviam “[...] quase duzentas famílias, que [tinham] suas casas construídas de taipa e pau-a-pique, umas cobertas até de telhas, outras em armação" (O IMPARCIAL, 1972b, p. 12), como parte de uma Campanha de despalafitação da capital.

\begin{abstract}
A área a ser ocupada totalmente, dentro de pouco tempo, destina-se a congregar todo pessoal residente em zona palafitada da capital, começando pelas vítimas do incêndio irrompido na outra margem da Avenida Kennedy, em princípios deste ano, resultando a destruição total de aproximadamente 120 casebres. Esse pessoal já está morando ali em quadras traçadas pela SURCAP, em número de 16, constituindo 224 lotes de terrenos. Os demais moradores de outros bairros como Vila Palmeira, Coroados, Avenida dos Franceses, etc, deverão se deslocarem para essa área da SURCAP.” (O IMPARCIAL, 1972b, p. 12).
\end{abstract}

O projeto de despalafitação de São Luís, lançado na administração do prefeito Haroldo Tavares (1971-1975), previa a transferência de 50.000 pessoas para lotes de 10 x 25 metros, financiados pelo $\mathrm{BNH}$ a preços estimados entre 10 a 12 cruzeiros mensais, em zona urbanizada, com água, luz, rede de esgotos, escolas etc. Apesar da plataforma midiática em torno do programa, tendo inclusive Costa Cavalcanti falado (como ministro do interior, em palanque armado na Praia da Areinha - bairro Madre de Deus) por ocasião da solenidade de abertura do convênio entre a prefeitura e o BNH, da "[...] preocupação que envolveu o Presidente Médici [1969 - 1974], quando de sua vinda a nossa capital, verificando, com os próprios olhos, as condições sub-humanas em que viv[ia]m os nossos palafitados" (O IMPARCIAL, 1972c, p. 12), as famílias que habitavam palafitas e casebres não tiveram como participar daquele plano, seja porque as condições de penúria em que moravam não lhes permitia arcar com os custos do financiamento, seja por não acreditarem no cumprimento das promessas feitas pelo prefeito ou, ainda, por não desejarem sair de onde estavam.

$\mathrm{Na}$ Vila Palmeira, especificamente, as famílias que estavam ameaçadas de despejo por ocuparem uma área pertencente ao Instituto da Previdência do Estado do Maranhão (IPEM), onde seria feito um conjunto habitacional para os servidores do estado, nem por isso animaram-se com os lotes do $\mathrm{BNH}$, insistindo em permanecer naquele lugar. Por esta razão, o IPEM apelou ao governador Pedro Neiva de Santana (1971 - 1975) "[...] por uma possessão de terras no Calhau, na margem direita da MA53 [...] evitando, assim, [que] fosse criado um problema social de proporções calamitosas, com o despejo de toda aquele gente pobre" (O IMPARCIAL, 1972d, p. 1).

Nessa lógica, parece que a Política Nacional de Habitação não gozava de boa fama em São Luís. Em 1973,

Continua[va] sendo efetuado o levantamento dos mutuários em atraso com as mensalidades de casas da COHAB [...] E o Departamento Jurídico [...] já est[ava] de posse de 500 ações de despejo, acreditando-se que outras est[avam] sendo preparadas [...] Por outro lado, o [...] advogado da Companhia de Habitação Popular do Maranhão, declarou estar estudando uma fórmula, junto aos mutuários devedores, a fim de que não se processem os despejos em massa, dos moradores dos três conjuntos (O IMPARCIAL, 1973, p. 1). 
O problema da moradia popular seguiu sua dinâmica pelos anos seguintes sem grandes alterações, havendo constante instabilidade nas "invasões" espalhadas pela cidade. Grupos sociais que inscreveram suas marcas na paisagem urbana, transformando aquele espaço no movimento da própria sobrevivência (CERTEAU, 2012). Urbanização desequilibrada que provocara “[...] escassez de habitação, levando à constituição de cortiços e favelas; [...] insuficiência de serviços urbanos essenciais, como transporte público, abastecimento de água, rede de esgoto, ou de equipamentos como hospitais, escola etc." ( GOUVÊA, 2005, p. 30). Em resposta a esta resalidade, os moradores desta localidade formaram em 1975, “[...] uma comissão para procurar o [...] Diretor-presidente das Centrais Elétricas do Maranhão (CEMAR) e solicitar a instalação [da] energia, já [...] que a Vila Palmeira [era] talvez o único bairro de São Luís que ainda não conta[va] com luz" (O IMPARCIAL, 1975a, p. 5). Porém, no final do ano, o bairro continuava desabastecido sem os mínimos serviços de infraestrutura, embora viessem a ser implantados, "[...] pelo menos no que se refere à instalação de iluminação, que é uma das principais necessidades, já que em água nem se fala, porque não há mesmo [...] Além de muita pobreza e poeira, naqueles arredores est[ava] alojada uma quadrilha de marginais que [vinha] deixando em polvorosa toda a região [...]" (O IMPARCIAL, 1975b, p. 5).

O levantamento socioeconômico feito por assistentes sociais da Superintendência de Urbanismo e Planejamento (SURPLAN) detectou que os habitantes eram trabalhadores "[...] braçais sem emprego fixo e empregados que ganha[va]m um salário mínimo [e] alguns comerciantes que surgiram ali com meras 'quitandas' [...] enriquecendo a custa daquilo que a pobreza compra, e que nem sempre é vendido a preços razoáveis" (O IMPARCIAL, 1975c, p. 7), quase todos de origem rural. Agruparam-se em ruas desalinhadas e sem calçamento que formavam uma comunidade carente de escolas, serviços de saúde, segurança, habitação, saneamento etc., sem receber atenção do poder público, a não ser "[...] a polícia [que] andou por aqui no começo, e derrubava as armações de casas, avisando que era proibido construir: mas não teve jeito [...] os casebres de taipa, tapad[o]s de barro e com cobertura de palha [...] se multiplica[ra]m por todos os lados" (O IMPARCIAL, 1975c, p. 7). Além disso, a Vila Palmeira figurou com muita frequência nas páginas policiais dos jornais de São Luís, que fizeram circular representações negativas do bairro, àquela época "a maior invasão" da capital. Estigmatizada socialmente e desassistida pelo Estado, não parava de crescer. Com mais de 2.800 casas erguidas desordenadamente e habitadas por pessoas de baixíssima renda e expobradas, "[...] segundo observações da assistência social, por toda espécie de delinquência, a par de desnutrição e, consequentemente, desidratação recorde e uma importante gama, ainda, de outras doenças (O IMPARCIAL, 1976a, p. 1), mesmo assim, este bairro se instituía na urbe e lutara por direitos de socialização, escolarização e cidadania.

Nesse sentido, outros princípios de diferenciação diversos poderiam dar conta dos desvios culturais se tratássemos dos objetos, das formas, dos códigos, e não dos grupos sociais. "De fato, as clivagens culturais não estão forçosamente organizadas segundo uma grade única do recorte social, que supostamente comandaria tanto a presença desigual dos objetos como as diferenças nas condutas" (CHARTIER, 2005, p. 181). A perspectiva invertida deve traçar de início a área social compósita em que circulam um corpus de textos ou uma classe de impressos, uma produção ou uma norma cultural, um Colegio de Aplicação como instituição de $1^{\circ}$ e $2^{\circ}$ graus ou um corpo de professores e funcionários dispostos a irradiar conhecimentos, valores e condutas de outra ordem, retroalimentando-se consecutivamente de uma cultura de bairro/local que depende para além do social, das pertenças sexuais ou geracionais, das adesões religiosas e das tradições educativas, das solidariedades territoriais e dos hábitos do ofício.

Este levantamento era parte do projeto de urbanização do bairro, elaborado por técnicos da SURPLAN, durante a gestão do prefeito Antônio Bayma Júnior (1975 - 1978). Das visitas feitas, nasceu a sugestão de transferir aquelas famílias para um local mais apropriado ou pelo menos remanejá-las temporariamente, pois segundo o relatório final era inviável qualquer tentativa de intervir na área naquelas condições, com “[...] a construção de casebres [...] invadindo os mangais existentes nos arredores [...]" (O IMPARCIAL, 1976b, p. 7). Sem embargo, apesar desta tentativa, não houve nenhum remanejamento, provavelmente porque ninguém quis largar seu pedaço de terra, por medo de perder o seu único espaço de sobrevivência; por outro lado, a União dos Moradores continuou reivindicando providências em relação à instalação da rede elétrica. O rápido crescimento populacional colocou a Vila Palmeira sob o 
olhar dos vereadores e de outras autoridades, despertando interesses eleitorais e preocupações governamentais. A população, por sua vez, usou isso como tática de apropriação para conseguir a iluminação elétrica e outros equipamentos urbanos; milhares de famílias que, sem meios para planejar o futuro, criavam as condições de sobrevivência e permanência como pertencimento do local. Em 1980, o prefeito Roberto Macieira (1980-1983) autorizou o envio de máquinas do Departamento Municipal de Estradas de Rodagem (DMER) para os trabalhos de terraplanagem de várias ruas do bairro, "[...] um dos maiores aglomerados urbanos da periferia de São Luís e dos mais carentes de serviços públicos" (O ESTADO DO MARANHÃO, 1980d, p. 1). Concentração demográfica e carência social que certamente pesaram muito na escolha da localidade para receber uma das obras do PREMEN; equipamento escolar cuja chegada provocou grande expectativa, seja no consumo de bens simbólicos, seja na realização comunitária/pessoal via escolarização que visara a inserção no mercado de trabalho e a integração social.

\section{O PROJETO DE REESTRUTURAÇÃO DO COLUN}

Na década de 1970, além da continuação e ampliação dos projetos João de Barro, Bandeirante e TV Educativa, a inclusão do Maranhão no Programa de Expansão e Melhoria do Ensino Médio (PREMEM) na gestão do governador Pedro Neiva de Santana (1971-1975) foi fruto de um acordo assinado entre o Ministério da Educação (MEC) e a Agência dos Estados Unidos para o Desenvolvimento Internacional (USAID), tendo como meta inicial a criação de um Ginásio Polivalente em cada capital. Com base nos High School norte-americanos ${ }^{5}$ que, por sua vez, tinham alguma inspiração em John Dewey (referência da educação escolanovista nos Estados Unidos), deveriam funcionar como modelo na difusão de um currículo capaz de unir humanismo, ciência e tecnologia, com disciplinas de formação geral (matemática, ciências, letras) e especial (técnicas agrícolas, comerciais, industriais e Educação para o lar) (PEDROSA \& BITTENCOURT JÚNIOR, 2015). Sua implantação demandava investimentos internacionais, nacionais e locais (SANTOS, 2012), visto que previa uma estrutura moderna e ampla com laboratórios e oficinas para dar suporte à formação projetada. Em 1971, no seu primeiro discurso como Secretário Estadual de Educação, o Professor Luiz Rêgo garantia que

A Secretaria está atenta às obrigações do Convênio para o recebimento de um Ginásio Modelo, a ser instalado em São Luís. Cumprindo recomendação do Senhor Governador Pedro Neiva de Santana, já estivemos na Guanabara, em contato com os técnicos do PREMEM. O Ginásio é orientado para o trabalho, localizado na Avenida dos Franceses. Decorrente de auxílios da USAID. O Estado o receberá construído, o professorado e a administração reciclados na sua atualização, preparados os professores das práticas educativas, instaladas quatro oficinas. É a partida para modificar o panorama do ensino verbalístico e acadêmico (O IMPARCIAL, 1971, p. 4).

Mas o Ginásio Polivalente da Avenida dos Franceses ${ }^{6}$, que deveria ser modelo, tornou-se uma experiência fracassada, sobretudo, porque de todas as condições previstas para o seu funcionamento, a construção e a equiparação do prédio foram as únicas ações concretizadas, inaugurando-se tardiamente com a presença do ministro da educação Jarbas Passarinho, em 1973. Neste sentido, não houve a qualificação docente e técnica anunciada. Os poucos professores, além de mal remunerados e inicialmente sem vínculo definitivo com o Estado, foram incorporados lentamente, mas ainda impossibilitados da dedicação exclusiva. Ou seja, em 1976, este Ginásio estava prestes a “[...] cerrar suas portas, por não oferecer as condições mínimas de funcionamento de um estabelecimento do gênero" (O IMPARCIAL, 1976c, p. 6).

\footnotetext{
${ }^{5}$ Desde a primeira década do século XX, a tendência do Brasil aparelhar-se e comparar-se ao currículo do sistema norteamericano de ensino, era uma prática concreta. Segundo Barbosa de Godois (1910), "Os Estados derrama[va]m a instrução em escola de um só mestre (escolas isoladas) e em escolas graduadas que receb[ia]m o nome de infant school, em que [eram] lecionadas - leitura, escripta, calculo, desenho, musica, geographia, moral e linguas allemã e ingleza; primary school, em que a essas materias se junta[va]m - história, arithmetica, algebra e physica; grammar school, em que se ensina[va]m, alem d'essas disciplinas, economia política, sciencias physicas e naturaes, cosmograpfia, logica, latim e grego e high school, cujo programma correspond[ia] aos dos cursos superiores"'(p. 6).

${ }^{6}$ Onde atualmente funciona o Colégio 02 de Julho, do Corpo de Bombeiros Militar do Maranhão.

Educação em Revista|Belo Horizonte|v.37|e25241|2021
} 
Em 1972, por outro lado, no contexto de adaptação à Lei 5.692, de 11 de agosto de 1971, ao ampliar-se a obrigatoriedade do ensino de quatro para oito anos, entre outras alterações, não só se divide a educação básica em dois graus (o $1^{\circ}$, unificando-se o primário ao ginásio e, extinguindo-se os exames de admissão para este último, e o $2^{\circ}$, integrando-se colegial e técnico pela via da profissionalização); como também, é absorvido o programa de Expansão e Melhoria do Ensino Médio pelo novo PREMEN (Programa de Expansão e Melhoria do Ensino de $1^{\circ}$ e $2^{\circ}$ graus), ao focalizar-se no aperfeiçoamento destes níveis de ensino. Suas ações se materializaram em novas modalidades, Centros interescolares, Colégios integrados ou Unidades integradas para viabilizar a implantação da Lei nos estados onde o atendimento educacional era mais deficitário. Este era o caso do Maranhão, principalmente, no que se refere ao $2^{\circ}$ grau, majoritariamente nas mãos do setor privado. Até 1978 , era oferecido em poucos estabelecimentos públicos, dos quais 6 estavam na capital, a saber: Liceu Maranhense, Centro de Ensino Gonçalves Dias e Centro de Ensino Coelho Neto (rede estadual); Escola Técnica Federal, Colégio Agrícola e Colégio Universitário (rede federal). Entre as cidades interioranas, a rede estadual possuía $2^{\circ}$ grau público em: Imperatriz, Caxias, Chapadinha, Pedreiras e São Bento.

Nesse cenário, o PREMEN entregou à Secretaria Estadual de Educação 6 prédios, feitos no padrão arquitetônico do Ginásio Polivalente. Exceto Caxias e Imperatriz, com uma unidade cada, estas novas instalações de ensino estavam localizadas em São Luís, sendo uma no Bairro de Fátima, outra na Vila Ivar Saldanha e duas na Vila Palmeira. As últimas (a Unidade Integrada Laura Rosa, para o ensino de $1^{\circ}$ grau e o Centro de ensino de $2^{\circ}$ grau Cônego José de Ribamar de Carvalho) foram construídas na perspectiva de um mesmo complexo escolar, no intuito de servir como modelo para a implementação do programa. Obras que projetavam o ensino de $1^{\circ}$ e $2^{\circ}$ graus nos moldes previstos pela Lei $n^{\circ}$ 5.692/1971. A efetivação do modelo de ensino previsto pelo programa, no entanto esbarrava nos problemas de qualificação e profissionalização docente que ainda eram muito graves naquela conjuntura.

Por outro lado, a pouca expressividade do Colégio Universitário era injustificável, se levarmos em conta que o panorama do ensino de $1^{\circ}$ e $2^{\circ}$ graus reclamava modificações urgentes em relação ao quantitativo de escolas, mas também no que diz respeito à formação de professores e aos métodos de ensino empregados. Defasagem sentida no ensino superior pelos altos índices de reprovação dos vestibulares e de evasão nos cursos de graduação. Realidade educacional que comprometia os projetos de modernização administrativa, agrícola e industrial do estado. Em 1980, o resultado do vestibular da UFMA expôs o quadro desolador do $2^{\circ}$ grau: "[...] pelas suas características de reprovação ainda nas primeiras provas, e[ra] um grito de alerta para a péssima qualidade do ensino no curso médio" (O IMPARCIAL, 1980a, p. 1). Crise do ensino que afetava todos os níveis ou etapas de escolarização, na medida em que,

[...] há muito [vinha] sendo criticado pela sua ineficácia em todos os níveis, partindo da $1^{\mathrm{a}}$ série do $1^{\circ}$ grau até a Universidade onde a evasão escolar atinge limites assustadores. O despreparo dos professores que escolhem o "magistério" para fazer bicos ou simplesmente são aceitos nos Colégios de baixa qualidade de ensino, por ínfimos salários de até 15 cruzeiros por hora/aula, têm contribuído para falir desesperadamente o ensino (O IMPARCIAL, 1980b, p. 7).

Falência do ensino que não se verificava somente nas escolas particulares, geralmente instaladas em espaços inapropriados e com a maioria dos professores leigos; mas também na rede pública, principalmente nas escolas primárias que se multiplicavam sem nenhum planejamento para atender a crescente demanda das áreas de maior concentração demográfica e nem se tinha em conta o despreparo dos professores nem a escolha feita pelo magistério para fazer "bicos" como é denunciado pela imprensa local. Quadro do ensino primário que se aproximava do mais completo caos nos bairros de São Luís.

Preocupado com a baixa qualidade do ensino desde o primeiro grau e a expansão do contingente estudantil na idade infantil, o prefeito de São Luís, Mauro Fecury [1979 -1980], est[aria] estudando um plano de utilização de todas as sedes de união de moradores nos bairros para [a] instalação de escolas públicas. O plano já est[ava] sendo levado ao conhecimento da população, pelo deputado federal João Alberto de Sousa, que [vinha] mantendo encontros sistemáticos com os presidentes de União de Moradores, conscientizando-os da importância do projeto que visa[ra] oferecer educação a milhares de crianças a nível de primário (O IMPARCIAL, 1980c, p. 5). 
Diante desses clamores e apoiada "[...] nas diretrizes do Ministério de Educação e Cultura, visto que o Aviso Circular 935/79 [...] aconselha[va] à universidade brasileira a desenvolver experiências novas e ativa participação nos programas estaduais e municipais de educação" (COLUN, 1980, p.1), a UFMA propôs a ampliação do Colégio Universitário a partir de 1980, com vistas a torná-lo modelo de ensino-aprendizagem; projeto de reestruturação conduzido por um grupo de professores da antiga faculdade de educação, àquela altura já desmembrada em dois departamentos: Educação I e II. Apresentado como "[...] ideia [que] visa[va] a valorizar a carreira do magistério, capacitando professores para um melhor desempenho da nobre tarefa de ensinar"(COLUN, 1980, p.1), o documento trazia em seu bojo as estratégias da UFMA no intuito de atuar em favor da construção de uma sociedade moderna.

Preocupada em melhorar os programas de ensino oficial e particular, a Universidade revela plena consciência de seu papel como legítima instituição social. Para executar o projeto de reestruturação do Colégio Universitário, foi criado um grupo de trabalho, constituído de dois coordenadores (Joseth Coutinho Martins Freitas e Maria de Jesus Pinto Ferraz), seis componentes (Conceição de Maria Pires Ferreira Lago, Conceição de Maria Ribeiro Quadros, Durval Cruz Prazeres, Lucinete Marques Lima, Maria Michel Pinto de Carvalho e Vanilda Loyola Rodrigues), quatro colaboradores (Maria Theresa Soares Pflueger, Nizeth Carvalho Bastos, Paula Franssineti Silva e Souza e Ruth Cunha Diniz) e uma assessoria especial (COLUN, 1980, p. 1).

Segundo José Maria Cabral Marques, à época reitor da UFMA (1979 - 1988), “[...] cada ano, o Colégio Universitário funcionava num prédio, numa sala [...] e tinha problemas de professores [;] problemas de tudo [...] mas não pode[ria] continuar assim [...]” (FARIA \& MONTENEGRO, 2005, p. 296). O levantamento das condições deste estabelecimento mostrou a inadequação das instalações físicas, a insuficiência do seu quadro docente, concluindo que "[o] Colégio não consegui[ra] alcançar integralmente seus objetivos por razões de ordem técnica e administrativa e a inadequação às diretrizes preconizadas pela legislação específica" (COLUN, 1980, p. 5). Ressentindo-se da falta de um prédio escolar, onde houvesse espaço e tempo dedicados com exclusividade às práticas educativas "[...] que atuam e influenciam a vida dos sujeitos, de modo amplo, difuso e imprevisível" (FRANCO, 2006, p. 536); e às práticas pedagógicas, as quais "[...]se realizam para organizar/potencializar/ interpretar as intencionalidades de um projeto educativo [...] por um pensamento reflexivo sobre o que ocorre [...] bem como por um pensamento crítico do que pode ser a prática educativa" (FRANCO, 2016, p. 537-538); o Colégio teve dificuldades no que tange ao ordenamento pedagógico. Além do mais, por ser seu públicoalvo pouco significativo diante da necessidade de estágio dos licenciandos, muitos dos quais eram professores em atividade nas redes pública e privada - embora ainda não tivessem o diploma -, esta realidade faz com que se fortaleça o discurso dos técnicos e professores da universidade em favor da reestruturação. Mudança que contribuiria de modo “[...] natural ao aprimoramento e elevação da qualificação dos docentes de $1^{\circ}$ e $2^{\circ}$ graus do Maranhão" (COLUN, 1980, p. 6); embora, por outro lado, " [o]s entendimentos com a Secretaria de Educação do Estado evidencia[sse]m a disponibilidade em dois Colégios integrantes do Complexo escolar da Vila Palmeira, edificados e aparelhados para o ensino de $1^{\circ}$ e $2^{\circ}$ graus" (COLUN, 1980, p. 1).

As unidades do PREMEN na Vila Palmeira, localizadas na Rua do Arame, s/n, formavam um mesmo conjunto arquitetônico concebido na perspectiva de um complexo escolar. Em 1979, diante da pressão dos moradores que reclamavam melhorias para o bairro, a Unidade Integrada Laura Rosa entrou em funcionamento no prédio do $1^{\circ}$ grau, abrindo matrículas para 600 alunos; atendimento aquém do esperado, se considerarmos a estrutura física disponível: 19 salas de aula somente para o $1^{\circ}$ grau, a possibilidade de oferta em pelo menos 2 turnos e a enorme concentração populacional na área. Obra subutilizada que parecia caminhar para o mesmo destino do Ginásio Polivalente da Avenida dos Franceses, evidenciando-se a ineficiência das políticas educacionais como antiga marca dos governos maranhenses ${ }^{7}$. Enquanto a população cobrava e aguardava a abertura do outro prédio, onde deveria

\footnotetext{
${ }^{7}$ Segundo Castellanos, “A instantaneidade cinematográfica dos governos no Maranhão do I e II Reinado, e a não continuidade ou má administração no curral governamental (MEIRELLES, 2001), sustentadas pelas lutas do dualismo partidário entre conservadores e liberais, trouxeram consigo o não cumprimento de reformas ao longo prazo, seja no cenário social, seja no educacional. Presidentes de expedientes que não podiam (pela dinamicidade na constante mudança administrativa das suas funções) planejar reformas que visassem o melhoramento do bem público e muito menos executá-las; se considerarmos que Educação em Revista|Belo Horizonte|v.37|e25241|2021
} 
funcionar o $2^{\circ}$ grau, a Secretaria de Educação acabou acertando a implantação do Colégio Universitário naquele local, mediante convênio com a Universidade Federal do Maranhão.

Nesta perspectiva, embora o prédio e o local escolhidos permaneçam e possam ser observados por meio das representações registradas na imprensa, o papel da instituição como tecnologia projetada parece obscuro, já que as formas de operacionalizar, as diversas descomodidades e as irregularidades implícitas na dinâmica de qualquer espaço escolar, como também as saídas, as conveniências e os ambientes circundantes que derivam destes estabelecimentos, e mesmo a qualidade da luz e do aquecimento ou não das salas de aula não foram mencionados nem descritos na garimpagem dos registros. Nessa lógica, embora o designer seja tratado como uma qualidade da arquitetura e da construção exacerbando-se sua imagem simbólica e estratégica de poder e de aclamação, na realidade tem significados e sentidos reais e distintos para os professores, na medida em que práticas pedagógicas ou educativas, recursos em uso ou intencionalidades na aprendizagem decorrem da forma como uma escola foi cogitada para projetar as ideias de instituições, educação e público consumidor que defende e para que foram criadas: o fomento da produção em massa e a eficiência social. Movimentos de eficiência industriais que enfatizaram formas particulares de organização escolar, controle social e cursos diferenciados, onde a tecnologia ao referenciar a arquitetura escolar, o ordenamento pedagógico, o equipamento escolar como cultura material da escola, os tempos escolares, a compartimentação do currículo e das disciplinas, as divisões por turma, idade e maturidade cognitiva e os recursos usados, se coloca dentro de uma forma pedagógica particular; sistema de produção da forma escolar de escolarização que se sustenta na eficiência industrial, no controle social e na tecnologia para produzir uma forma gerencial e material que se destina a reproduzir ou produzir práticas específicas segundo intencionalidades desencarnadas (VIÑAO FRAGO, 2001).

Segundo o reitor José Maria Cabral Marques, optou-se pela Vila Palmeira porque os prédios

[...] tinha(m) tudo para ser um grande empreendimento da Universidade, principalmente no aspecto social e educacional. Tratava-se de um bairro pobre, totalmente desprotegido na área de escola, e nós íamos dar a ele uma escola de qualidade. Disse ao governador João Castelo [1979 - 1982]: 'Governador, o senhor vai ganhar e não vai ter que manter esses prédios. A Universidade os manterá. O senhor deixa os professores de $1^{\circ}$ Grau, que já estão lá, e, se puder, nos dá mais alguns funcionários da área administrativa, para nos ajudar no $2^{\circ}$ grau; quanto aos professores e alunos do $2^{\circ} \mathrm{Grau}$, ficam sob nossa responsabilidade'. Ele foi formidável. Percebeu a significação social para aquele bairro e fez como eu pedira, sem colocar nenhuma resistência [...] Estabelecemos que só podia estudar no Colégio da Vila Palmeira quem morasse lá, porque, senão, dentro em breve, a qualidade do Colégio subia e todo mundo ia querer botar seu filho lá, mesmo havendo uma prova de seleção, como de fato aconteceu (FARIA \& MONTENEGRO, 2005, p. 297).

Para além do "aspecto social e educacional" ou da "significação social", a solução encontrada, na verdade, poupava a Universidade do encargo de construir um prédio, e o governo estadual da responsabilidade de manter um Colégio com aquelas dimensões, evitando algo semelhante ao que tinha se dado com o Ginásio Polivalente da Avenida dos Franceses. Assim, após uma peregrinação pelo centro da cidade, desde o Palácio Cristo Rei (1968-1971) ${ }^{8}$, Quinta do Macacão (1972-1973) e Rua das Hortas $(1974-1975)^{10}$ e por prédios como o Pombal ${ }^{11}$ e o Pimentão ${ }^{12}$, no Campus do Bacanga (1975-1979), o

pela vaidade pessoal de alguns governantes, em vez de se complementarem algumas grandes obras já começadas, preferiam descartá-las, apagando assim a imagem pública de seus antecessores” (2007, p. 82). Como exemplos desse marasmo de políticas sem aplicação, podemos citar também, a instituição das escolas normais destinadas à formação de professores que, segundo os próprios presidentes de província e/ou governantes do estado, "não teve o efeito esperado", principalmente porque era enorme o descompasso entre a preparação teórica recebida pelos formandos e a difícil realidade das escolas no interior do Maranhão (CASTELLANOS, 2007), e o funcionamento dos grupos escolares que, na verdade foram marcados pela precariedade em termos de instalações físicas e de formação/valorização dos seus professores (SILVA, 2017).

${ }^{8}$ Onde funcionou, nesse período, a reitoria e a Faculdade de Filosofia, Ciências e Letras da FUM.

${ }^{9}$ Praça do centro histórico de São Luís.

${ }^{10}$ Onde funcionou, nesse período, a Faculdade de Educação da FUM.

11 Atual Centro de Estudos Básicos, na cidade universitária.

12 Atual Centro de Ciências Sociais, na cidade universtária. 
Colégio Universitário preparava a sua transferência para a Vila Palmeira, com o objetivo de concretizar a sua ampliação como Colégio de Aplicação. Entretanto, a decisão de garantir todas as vagas para quem morasse no bairro, no sentido de "dar a ele uma escola de qualidade", não foi estabelecida de imediato. Em janeiro de 1980,

A Coordenadora do $1^{\circ}$ grau ordenou a suspensão das matrículas dos novos estudantes na Unidade Integrada Laura Rosa na Vila Palmeira, que no ano passado matriculou seiscentos alunos e agora até o momento devido à nova norma estabelecida recebeu um contingente de apenas quatrocentos escolares, pois muitos tem se dirigido até lá debalde, sem conseguirem as esperadas vagas, fato que vem revoltando muitos professores e pais que estão na [i]minência de deixarem seus filhos sem escola, já que não podem pagar as caras mensalidades exigidas pelos Colégios particulares, dizendo os mesmos também, que segundo o que se comenta, isto se deve ao fato do prédio daquele estabelecimento haver sido cedido pela Secretaria de Educação à Universidade Federal do Maranhão [...] pais de alunos [...] possuídos de uma grande revolta relataram a situação em que vivem seus filhos no momento, sem conseguirem vagas para estudar [...] Uma das funcionárias do Laura Rosa que não quis dar o nome acentuou: "esta situação é realmente muito difícil, pois as crianças daqui são geralmente filhas de pais pobres, que não podem pagar Colégios particulares e, às vezes, nem sequer ônibus todo dia para outro local distante, e o que se vê é que estão aceitando matrículas apenas dos já veteranos, e quem precisa entrar para estudar, como é que fica?" (O ESTADO DO MARANHÃO, 1980a, p. 6, grifo nosso).

Percebe-se que, de início, a Universidade não pretendia atender todo o contingente da Vila, talvez pelo desejo de nivelar os alunos pela seleção, como era a tradição do Colégio, ou por querer abarcar outros bairros próximos, dada a carência de escolas naquela região da cidade, ou ainda por não pretender ou não ter condições de contratar professores em quantidade suficiente para esse atendimento. Nota-se também que os funcionários da Unidade Integrada, absorvidos pela Universidade nos termos do acordo, eram pessoas ligadas à comunidade que defendiam o ponto de vista dos pais em conflito com os interesses do Colégio. Somente com estes movimentos ocorridos antes da inauguração do prédio do $2^{\circ}$ grau, onde ficaram evidentes as táticas de apropriação e resistências daqueles moradores de recorrer à imprensa para mostrar sua insatisfação, e a partir dos primeiros contatos da universidade com o bairro, o projeto de reestruturação começou a ganhar seus contornos definitivos, ao determinar-se a prioridade àquela comunidade:

Um dos bairros de São Luís, com população estável, mas de baixa renda, a Vila Palmeira apresenta[va] acentuado índice de desemprego. Apesar de possuir uma força de trabalho em que predomina[va] a mão-de-obra desqualificada, mostra[va]-se interesse em melhorar as condições de vida (COLUN, 1980, p. 2).

O prédio do $2^{\circ}$ grau abriu suas portas no dia 15 de março de 1980 , em comemoração ao primeiro ano do governo de João Castelo (1979-1982). Na ocasião, foi anunciado "trata[r]-se de um Colégio Universitário, cuja clientela escolar ser[iam] os próprios alunos do bairro Vila Palmeiras" (O ESTADO DO MARANHÃO, 1980b, p. 4). Ato inaugurativo que pode ser lido como síntese ou ponto de convergência de vários interesses: do governo, que queria imprimir sua marca associando seu nome àquela obra; da política educacional iniciada com a ideia de um Ginásio Polivalente que terminava se materializando em outra modalidade escolar; dos professores e técnicos da Universidade que desejavam reestruturar o Colégio Universitário, efetivando-o como escola-laboratório, campo de estágio, veículo para melhoria do ensino e espaço de educação permanente e de adultos; dos moradores da Vila Palmeira que em sua maioria não eram escolarizados e tampouco podiam pagar pela educação dos filhos, mas sonhavam vê-los num Colégio público e qualificado. Neste momento de lutas de representações (BARROS, 2003), era o governador que aparentemente levava mais vantagem. Em meio às crianças pobres, ele vinculava sua imagem àquela realização histórica. Autoridade, coações e reações, que reforçam nos poderosos dissimulados dispositivos de autocoerção, caracterizando "[...] cada formação ou figuração social a partir da rede específica das interdependências que aí ligam os indivíduos uns aos outros, [compreendendo-os diretamente] em sua dinamicidade, reciprocidade e nas relações mantidas pelos diferentes grupos" (ELIAS, 2001, p. 23). Imagem simbólica (PESAVENTO, 2012) reforçada no discurso do Secretário de Educação, Raimundo Medeiros Lobato, ao relacionar a política educacional do Estado àquilo que era apenas um horizonte perseguido pelo Colégio Universitário. 
Melhorar a qualidade do ensino é adequá-lo à realidade do educando, é dar reais condições de aprendizagem, oferecendo professores mais motivados, porque melhor formados e pagos, oferecendo material escolar, instalações e equipamentos indispensáveis ao trabalho de professores, é tornar a aprendizagem uma resposta aos enigmas e problemas da vida $(\mathrm{O}$ ESTADO MARANHÃO, 1980b, p. 4).

Os agentes sociais presentes naquela cerimônia, por outro lado, também se utilizaram a seu modo, dentro das possibilidades e de forma não planejada ou talvez até inconsciente, da visibilidade dada pelos jornais ao acontecimento. Se o governo utilizava o espetáculo para se promover, eles celebravam silenciosamente a conquista obtida por suas famílias que resistiram ante a possibilidade de transferência da Unidade Integrada para outro espaço e tiveram suas reclamações ouvidas, ao dizer que "[...] o governador do Estado e o Secretário de Educação deviam tomar uma providência para a Unidade Laura Rosa não sair daqui, pois atende a muitas crianças que precisam estudar com a vantagem de ser perto de onde a gente mora." (O ESTADO DO MARANHÃO, 1980a, p. 6). Imagem não menos simbólica, o gesto patriótico do governador e do seu secretário de educação, ao segurar as bandeiras nacional e estadual, que tinha como propósito político, produzir a representação de um governo que valorizava a educação como forma de "[...] fazer com que o Maranhão contribu[ísse] para a solução dos grandes problemas nacionais e regionais" (O ESTADO DO MARANHÃO, 1980c, p. 7). Gesto acompanhado pela multidão ali reunida, que embora flagrada pelos mesmos jornais numa postura de reverência aos símbolos nacionais, não era constituída apenas de participantes ativos da cerimônia ou culto cívico; ocupava na verdade, o espaço que estivera na iminência de ser "[...] desocupado para a Universidade do Maranhão" (O ESTADO DO MARANHÃO, 1980a, p. 6) e dele se apropriara como única forma de obter alguma moeda de troca para o mercado de bens simbólicos, no intuito de capitalizar possibilidades de ascensão social por meio do sucesso escolar (MICELI, 2007; LAHIRE, 2008; ZAGO, 2011).

Com isso, o COLUN ${ }^{13}$ teve seu novo perfil delineado pelas trocas culturais provenientes do cruzamento de interesses entre professores, estagiários, técnicos, alunos e moradores da comunidade. Relação de poder responsável pela concretização de um Colégio de Aplicação que se se manteve restrito até então, ao círculo classificatório da universidade, a partir de 1980 abarca a periferia como público-alvo; reestruturação não apenas em termos físicos, disciplinares, organizacionais ou da gramática escolar, mas sobretudo, no que tange à sua cultura específica ou identidade singular. Em outras palavras, "as relações econômicas e sociais não são anteriores às culturais nem as determinam; elas próprias são campos de prática cultural e produção cultural - o que não pode ser dedutivamente explicado por referência a uma dimensão extracultural da experiência" (HUNT, 1992, p. 9).

\section{CONSIDERAÇÕES FINAIS}

Dentro da perspectiva político-cultural de modernização da sociedade brasileira, referenciada no padrão civilizatório norte-americano, cuja forma social tem como eixos a dinamização urbanoindustrial e a busca pela universalidade dos processos de escolarização, que podem garantir que a herança cultural prevaleça sobre o fator hereditário, a ideia da democracia como configuração mais moderna da forma política atual ganhou força em plena vigência do regime autoritário; "[...] homens singulares que formam entre si figurações de tipos diversos ou sociedades que não são nada mais que figurações de homens interdependentes" (ELIAS, 2001, p. 41), onde a liberdade de ação e a margem de manobra da posição dependem do equilíbrio de tensões imposto pelos princípios de diferenciação e os desvios culturais.

Assim, os projetos educacionais financiados pelo Banco Mundial no âmbito dos acordos MEC-USAID, que visavam difundir ginásios polivalentes modelares para a reforma educacional, traziam em seu bojo as concepções pedagógicas oriundas do modelo escolar norte-americano. Ao mesmo tempo, as universidades brasileiras eram instadas a reconhecer no ensino de $1^{\circ}$ e $2^{\circ}$ graus o ponto de apoio para transformar a educação brasileira, em sintonia com o ritmo da modernização capitalista; situação que implicava o engendramento de uma nova cultura escolar de base democrática.

\footnotetext{
${ }^{13}$ Sigla que passou a identificar o Colégio a partir de 1980. 
Inserida no contexto de modernização do ensino a nível estadual, a transferência do Colégio Universitário para a Vila Palmeira em 1980, foi viabilizada pelo convênio entre a Universidade Federal e a Secretaria Estadual de Educação. Mediada pelo Programa de Expansão e Melhoria do Ensino (PREMEN) no âmbito dos acordos MEC/USAID, a implantação do Colégio de Aplicação naquele bairro foi a estratégia adotada pelo governo do estado e pela universidade com o objetivo de expandir o atendimento educacional para alcançar áreas carentes; dinamizar o ensino de $1^{\circ}$ e $2^{\circ}$ graus possibilitaria a inserção das classes populares no mercado agroindustrial e, sobretudo, constituiria o campo de estágio dos licenciandos da UFMA.

Destarte, o Colégio Universitário da Universidade Federal do Maranhão (UFMA), criado em 1968, como um $3^{\circ}$ ano Colegial preparatório ao ensino superior, torna-se Colégio de Aplicação para campo de estágio das licenciaturas da universidade, em 1972 (COLUN, 1972). A sua transferência para a obra do PREMEN, recém-construída no Bairro Vila Palmeira, em 1980, se dá pela inabilidade de sua função como campo de estágio que vinha cumprindo sofrivelmente, não só por julgarmos a insuficiente capacidade de absorção de alunos e a alta seletividade, como também pela oferta restrita ao então $2^{\circ}$ grau e a falta de um prédio próprio para seu funcionamento.

Para a comunidade, o Colégio representou a esperança de melhorias pelas quais seus moradores lutaram desde a ocupação da área na passagem da década de 1960 para a de 1970. Grupos sociais desprivilegiados de origem rural, com pouca escolaridade (habitantes da Vila Palmeira e de alguns bairros vizinhos - Barreto, Radional, João Paulo e outros), formaram o público atendido pelo COLUN. População estigmatizada pela imagem negativa em circulação pela cidade, notadamente via imprensa, onde eram representados sob o signo da violência e da miséria. População crescente que se originou do inchaço urbano verificado na ilha de São Luís durante as décadas de 1960 a 1980.

Dessa interação, configurou-se um campo social formado por membros da comunidade, do Colégio e da Universidade, em confronto com a política educacional do estado e do governo, que se posicionaram em torno de variados interesses entrecruzados e em diferentes frentes em defesa deste espaço escolar reinventado por eles: interlocutores ativos, na sua maioria, pertencentes ao local de disputa, que ao singularizarem suas ações lhe deram uma identidade própria e particular a esta instituição; Ginásio Polivalente em principio que se materializou noutra modalidade escolar: o Colégio de Aplicação do Maranhão, efetivado não só como escola-laboratório e campo de estágio das licenciaturas da universidade, como também um veículo para a melhoria do ensino e um espaço de educação permanente e de adultos. Cultura escolar em formação que se insere numa cultura local, um COLUN que ao se reinventar, projeta num bairro pobre de São Luís, uma ascensão no âmbito educacional, social e cultural.

\section{REFERÊNCIAS}

\section{a) Bibliografia}

CASTELLANOS, Samuel Luis Velázquez. Práticas de leitura no Maranhão na Primeira República: entre apropriações e representações. 174f. Dissertação (Mestrado em Educação) - Centro de Ciências Sociais, Universidade Federal do Maranhão, São Luís, 2007.

CASTELLANOS, Samuel Luis Velázquez. O livro escolar no Maranhão império: produção, circulação e prescrições. 450f. Tese (Doutorado em Educação Escolar) - Faculdade de Ciências e Letras, Universidade Estadual Paulista "Júlio de Mesquita Filho”, Araraquara-SP, 2012.

BARROS, José D'Assunção. História cultural: um panorama historiográfico. Textos de história, Brasilia, v. 11, n. 1/2, p. 145-171, 2003.

CERTEAU, Michel de. A invenção do Cotidiano: artes de fazer. Tradução Ephraim Ferreira Alves. 18. ed. Rio de Janeiro: Vozes, 2012, v. 1. 
CHARTIER, Roger. E1 mundo como representação: estúdios sobre história cultural. 6. ed. Barcelona: Editorial Gedisa, S. A., 2005.

ELIAS, Norbert. (2001). A sociedade de corte: investigação sobre a sociologia da realeza e da aristocraciade corte. Rio de Janeiro: Jorge Zahar Ed, 2001.

FARIA, Regina Helena Martins de; MONTENEGRO, Antônio Torres. Memória de professores: histórias da UFMA e outras histórias. São Luís: EDUFMA, 2005.

FAUSTO, Boris. A Revolução de 1930: historiografia e história. São Paulo: Companhia das Letras, 1997.

FERREIRA, Antônio José de Araújo. A produção do espaço urbano em São Luís do Maranhão: passado e presente; há futuro? São Luís: EDUFMA, 2014.

FRANCO, Maria Amélia do Rosário Santoro. Prática pedagógica e docência: um olhar a partir da epistemologia do conceito. Revista Brasileira de Estudos Pedagógicos, Brasília, v. 97, n. 247, p. 534551, set./dez, 2016.

GODOIS, Antonio Baptista Barbosa de. O mestre e a escola. Imprensa Oficial: São Luís, 1910.

GOUVÊA, Ronaldo Guimarães. A questão metropolitana no Brasil. Rio de Janeiro: FGV, 2005.

HUNT, Lynn. A nova história cultural. São Paulo: Martins Fontes, 1992.

KREUTZ, Arno. Projeto João de Barro: uma experiência oficial de educação popular no Maranhão. 139f. Dissertação (Mestrado em Educação) - Instituto de Estudos Avançados em Educação, Fundação Getúlio Vargas, Rio de Janeiro, 1982.

LAHIRE, Bernard. Sucesso escolar nos meios populares: as razões do improvável. 1. ed. São Paulo: Ática, 2008.

LEFEBVRE, Henri. O direito à cidade. Tradução: Rubens Eduardo Frias. São Paulo: Centauro, 2001.

LIMA, Carlos de. Caminhos de São Luís: ruas, logradouros e prédios históricos. São Paulo: Siciliano, 2002.

MICELI, Sérgio. Introdução: a força do sentido. In: Bourdieu, Pierre. A economia das trocas simbólicas. 6. ed. São Paulo: Perspectiva, 2007.

MOREIRA, Tiago Silva. Gestão metropolitana: a região metropolitana da grande São Luís e os desafios das políticas urbanas. 138f. Dissertação (Mestrado em Desenvolvimento Socioespacial e Regional) Centro de Ciências Sociais Aplicadas, Universidade Estadual do Maranhão, São Luís, 2013.

NASCIMENTO, Elizânia Sousa do. Desbravando inteligências para o desenvolvimento: o projeto bandeirante e a expansão do ensino secundário no Maranhão. 209f. Dissertação (Mestrado em Educação) - Centro de Ciências da Educação, Universidade Federal do Piauí, Teresina, 2013.

PEDROSA, José Geraldo; BITENCOURT JÚNIOR, Nilton Ferreira. Americanismo e educação para o trabalho no Brasil (1971-1974). Trabalho \& Educação, Belo Horizonte, v. 24, n. 1, p. 11-30, jan./abr. 2015.

PESAVENTO, Sandra Jatahy. História e História Cultural. Belo Horizonte: Autêntica, 2012. 
PINTO, Maria Núbia Bonfim. Do velho ao novo: política e educação no Maranhão. 222f. Dissertação (Mestrado em Educação) - Instituto de Estudos Avançados em Educação, Fundação Getúlio Vargas, Rio de Janeiro, 1982.

SANTOS, Sandra Regina Rodrigues dos Santos. Gestão Democrática: representações e potencialidades na atuação do Conselho Diretor e na construção do Projeto Político Pedagógico - o caso do Colégio Universitário em São Luís (1989-1997). São Luís: EDUEMA, 2012.

SILVA, Diana Rocha da. As casas de ensino no Maranhão: um estudo de sua representação no período republicano (1903-1912). 275f. Tese (Doutorado em Educação Escolar) - Faculdade de Ciências e Letras, Universidade Estadual Paulista "Júlio de Mesquita Filho", Araraquara, 2017.

SILVA, Maria do Socorro Moura da. Escola e comunidade: estudo das relações. São Luís: UFMA, 1987.

SOUZA, Nadjelena de Aaújo. De centro interescolar de segundo grau a Escola Técnica Estadual do Maranhão Dr. João Bacelar Portela: história e memória de uma instituição escolar (1980-1996). 275f. Dissertação (Mestrado em Educação) - Faculdade de Educação, Universidade de São Paulo, São Paulo, 2018.

VIÑAO FRAGO, Antonio. Do espaço escolar e da escola como lugar: propostas e questões. In: VIÑAO FRAGO, Antonio; ESCOLANO, Augustín. Currículo, espaço e subjetividade: a arquitetura como programa. Tradução: Alfredo Veiga-Neto. 2. ed. Rio de Janeiro: DP\&A, 2001. p. 59-139.

ZAGO, Nadir. Fracasso e sucesso escolar no contexto das relações família e escola: questionamentos e tendências em Sociologia da Educação. Sociologia da Educação (Revista Luso-brasileira), n. 3, p. 57-83, 2011.

\section{b)Legislação}

BRASIL. Decreto n 63.914, de 26 de dezembro de 1968. Provê sobre o Programa de Expansão e Melhoria do Ensino Médio (PREMEM) e dá outras providências. Coleção de Leis da República. v. 8, p. 454-456, out./dez. 1968. Brasília: Imprensa Nacional, 1968.

BRASIL. Decreto n ${ }^{\circ} 70.067$, de 26 de janeiro de 1972. Dispõe sobre o Programa de Expansão e Melhoria do Ensino e dá outras providências. Coleção de Leis da República. v. 2, p. 164-165, jan./mar. 1972. Brasilia: Imprensa Nacional, 1972.

BRASIL. Lei $n^{\circ}$ 5692, de 11 de agosto de 1971. Fixa Diretrizes e Bases para o ensino de $1^{\circ}$ e $2^{\circ}$ graus, e dá outras providências. Coleção de Leis da República. v. 5, p. 59-68, jul./set. 1971. Brasília: Imprensa Nacional, 1971.

MARANHÃO. Mensagem apresentada à Assembléia Legislativa pelo Governador José Sarney Costa. São Luís, 1967.

c) Arquivo Escolar

COLUN. Regimento interno do Colégio Universitário, 1972.

COLUN. Projeto de Reestruturação do Colégio Universitário, 1980.

d) Periódicos 
Problema dos excedentes Escolares Acha-se praticamente solucionado. O Imparcial, São Luís, p. 4, 24 março 1966.

Inauguração das 505 casas construídas: Anil. O Imparcial, São Luís, p. 8, 20 janeiro 1968 a.

O Problema habitacional de São Luís. O Imparcial, São Luís, p. 4, 21 janeiro 1968b.

Campo de Perizes sob asfalto. O Imparcial, São Luís, p. 4, 27 janeiro 1968c.

Perizes asfaltado no $2^{\circ}$ ano do Governo Sarney. Jornal do Dia, São Luís, p. 1, 31 janeiro 1968a.

Esfôrço governamental no setor da educação. O Imparcial, São Luís, p. 8, 08 março 1968d.

Educação matricula mais quatro mil e oferece ainda outras 1600 vagas. Jornal do Dia, São Luís, p. 5, 07 abril 1968b.

Nota. Jornal do Dia, São Luís, p.1, 21 maio 1968c.

Palafiteiros. O Imparcial, São Luís, p. 7, 14 setembro 1968e.

Os rumos da educação no Estado do Maranhão. O Imparcial, São Luís, p. 4, 23 março 1971.

Famílias temem desapropriações: para onde vamos? O Imparcial, São Luís, p. 6, 25 março 1972a.

Iniciada despalafitação na Av. Kennedy. O Imparcial, São Luís, p. 12, 11 outubro 1972b.

Iniciadas obras de despalafitação de São Luís. O Imparcial, São Luís, p. 12, 26 outubro 1972c.

Casas da V. Palmeiras não serão despejadas. O Imparcial, São Luís, p. 1, 11 novembro 1972d.

Cohab pondera sobre situação dos mutuários. O Imparcial, São Luís, p. 1, 21 janeiro 1973.

Energia para Vila Palmeira. O Imparcial, São Luís, p. 5, 12 abril 1975a.

Vila Palmeira terá mercado. O Imparcial, São Luís, p. 5, 23 novembro 1975 b.

Vila Palmeira: um quadro da maior invasão de S. Luís. O Imparcial, São Luís, p. 7, 06 dezembro 1975c.

Urbanização de Vila Palmeiras é dilema. O Imparcial, São Luís, p. 1, 05 março 1976a.

Escola Polivalente pode fechar. O Imparcial, São Luís, p. 6, 02 setembro 1976b.

Vila Palmeiras recebe energia. O Imparcial, São Luís, p. 7, 14 outubro 1976c.

$2^{\circ}$ grau está falido. O Imparcial, São Luís, p. 1, 10 janeiro 1980a.

Lobato aponta causas da falência do $2^{\circ}$ grau. O Imparcial, São Luís, p. 7, 11 janeiro 1980b.

Escolas públicas vão funcionar em União de Moradores. O Imparcial, São Luís, p. 5, 19 janeiro 1980c.

Crianças ameaçadas de ficar sem escola na Vila Palmeiras. O Estado do Maranhão, São Luís, p. 6, 24 janeiro 1980a. 
Secretaria de Educação entregou mais duas unidades escolares de $2^{\circ}$ grau. O Estado do Maranhão, São Luís, p. 4, 16 março 1980b.

365 dias de governo. O Estado do Maranhão, São Luís, p. 7, 16 março 1980c.

Vila Palmeira já será pavimentada. O Estado do Maranhão, São Luís, p. 1, 22 novembro 1980d.

Submetido: $09 / 09 / 2020$

Aprovado: 05/01/2021 